\title{
Low Cd content emitted by humans into the atmosphere
}

\author{
Dongfang Yang ${ }^{1,2,3}$ a, Linzhen Wei ${ }^{1}$, Shubo Fang ${ }^{2}$, Min Lu ${ }^{1}$, Danfeng Yang ${ }^{4}$ \\ ${ }^{1}$ School of International Economics, Shaanxi Institute of International Trade \& commerce, Xi'an 712046, China \\ ${ }^{2}$ Ecology and Environment College, Shanghai Ocean University, Shanghai 710123, China \\ ${ }^{3}$ North China Sea Environmental Monitoring Center, SOA, Qingdao 266033, China \\ ${ }^{4}$ The Fu Foundation School of Engineering and Applied Science, Columbia University, 10025, USA
}

\begin{abstract}
According to the data in May, September and October 1993, the variation range of Cd content in the water body of Jiaozhou Bay was $0.07-0.23 \mu \mathrm{g} / \mathrm{L}$, which conforms to the national water quality standard of Class I. It indicated that in May, September and October, the water in the entire water area of Jiaozhou Bay was not contaminated by $\mathrm{Cd}$ content. In May, the variation range of $\mathrm{Cd}$ content in the waters of Jiaozhou Bay was $0.09-0.18 \mu \mathrm{g} / \mathrm{L}$. In the coastal waters of the north of Jiaozhou Bay, the Cd content reached a relatively high value, which was $0.18 \mu \mathrm{g} / \mathrm{L}$. In September, the variation range of Cd content in the waters of Jiaozhou Bay was $0.07-0.23 \mu \mathrm{g} / \mathrm{L}$. In the coastal waters of the east of Jiaozhou Bay, the Cd content reached the highest value, $0.23 \mu \mathrm{g} / \mathrm{L}$. In October, the variation range of Cd content in the waters of Jiaozhou Bay was $0.08-0.18 \mu \mathrm{g} / \mathrm{L}$. In the coastal waters of the east of Jiaozhou Bay, the Cd content reached a relative high value, $0.18 \mu \mathrm{g} / \mathrm{L}$. In terms of Cd content, the water quality of Jiaozhou Bay had reached high quality. The water was clean, and it was not polluted by Cd content at all. The Cd content in the waters of Jiaozhou Bay mainly came from two sources, the transport of surface runoff and the transport of atmospheric deposition. The $\mathrm{Cd}$ content from surface runoff transportation was $0.18 \mu \mathrm{g} / \mathrm{L}$, and the $\mathrm{Cd}$ content from atmospheric deposition transportation was $0.18-0.23 \mu \mathrm{g} / \mathrm{L}$. The $\mathrm{Cd}$ content transported by atmospheric deposition was very close to the $\mathrm{Cd}$ content transported by surface runoff, and was very low, ranging from 0.18 to $0.23 \mu \mathrm{g} / \mathrm{L}$, far less than $1.00 \mu \mathrm{g} / \mathrm{L}$. This revealed that the humans had realized the importance of environmental protection, and the emissions to the environment were very low. The atmosphere, land and sea were not polluted by $\mathrm{Cd}$ content. The $\mathrm{Cd}$ content transported by atmospheric deposition $0.18-0.23 \mu \mathrm{g} / \mathrm{L} \geq$ the $\mathrm{Cd}$ content transported by surface runoff $0.18 \mu \mathrm{g} / \mathrm{L}$, which indicated that the Cd content was mainly discharged into the atmosphere by humans and then deposited on the land.
\end{abstract}

\section{Introduction}

With the increase of environmental awareness, the emission of waste water, exhaust gas and solid waste contained $\mathrm{Cd}$ in the production process is less and less. It appeared very little $\mathrm{Cd}$ content in the land, atmosphere, and ocean [1-7]. Based on the survey materials in 1993, this article studies the $\mathrm{Cd}$ content, horizontal distribution and its sources in the waters of Jiaozhou Bay, determines the water quality, and the transportation path and transportation volume of $\mathrm{Cd}$, providing scientific and theoretical basis for the study on the $\mathrm{Cd}$ sources, pollution degree and migration process.

\section{Survey waters, materials and methods}

\subsection{Natural environment of Jiaozhou Bay}

Jiaozhou Bay is located in the southern part of Shandong Peninsula. Its geographical position is between $120^{\circ} 04^{\prime}-120^{\circ} 23^{\prime} \mathrm{E}$ and $35^{\circ} 58^{\prime}-36^{\circ} 18^{\prime} \mathrm{N}$. It is bounded by the line connecting Tuan Island and Xuejia Island, and is connected to the Yellow Sea. With an area of about $446 \mathrm{~km}^{2}$ and an average water depth of about $7 \mathrm{~m}$, it is a typical semi-enclosed bay. There are more than a dozen rivers entering the sea in Jiaozhou Bay, among which the Dagu River, Yang River and the Haibo River, Licun River and Loushan River in Qingdao City with larger runoff and sand content. These rivers are all seasonal rivers, and the river hydrological characteristics have obvious seasonal changes $[12,13]$.

\subsection{Materials and methods}

The survey data of Cd content in Jiaozhou Bay in May, September and October 1993 used in this study are provided by the North Sea Monitoring Center of the State Oceanic Administration. Seven stations were set up in the waters of Jiaozhou Bay to take water samples: stations H3101, H3102, H3103, H3104, H3105, H3106 and H3107 (Figure 1). Sampling was conducted three times in May, September and October 1993, respectively.

\footnotetext{
adfyang_dfyang@126.com
} 
Water samples were taken according to the water depth (surface and bottom layers were taken when the depth $>10 \mathrm{~m}$, and only the surface layer was taken when the depth $<10 \mathrm{~m}$ ) for investigation and sampling. The survey of PHC content in Jiaozhou Bay water body was carried out by the national standard method, recorded in the national "Marine Monitoring Code" (1991) [9].

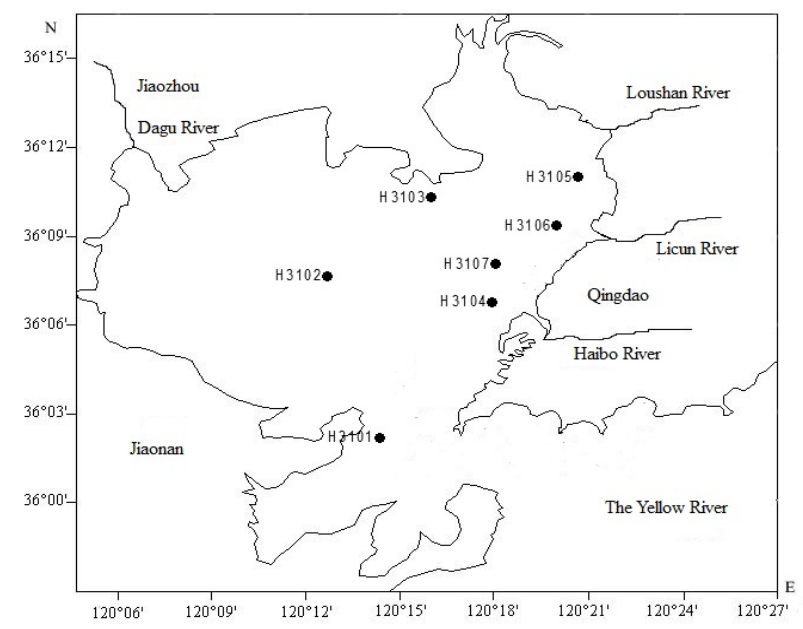

Fig.1 Investigation sites in Jiaozhou Bay

\section{Results}

\subsection{Cd content}

In terms of $\mathrm{Cd}$ content in the ocean, the nation has put forward the national seawater quality standards for Class I $(1.00 \mu \mathrm{g} / \mathrm{L})$. In May, September and October, the Cd content in the waters of Jiaozhou Bay ranges within $0.07-0.23 \mu \mathrm{g} / \mathrm{L}$, which conforms to the seawater quality standard of Class I.

In May, the variation range of $\mathrm{Cd}$ content in the waters of Jiaozhou Bay was $0.09-0.18 \mu \mathrm{g} / \mathrm{L}$ (Figure 1). The high value area appeared in the northern coastal waters of Jiaozhou Bay. In this area, station H3103, the $\mathrm{Cd}$ content was relatively high, which was $0.18 \mu \mathrm{g} / \mathrm{L}$, conforming to the seawater standard of Class I $(1.00 \mu \mathrm{g} / \mathrm{L})$. It indicated that in terms of Cd content, the water quality in the northern coastal waters conformed to the seawater standard of Class I $(1.00 \mu \mathrm{g} / \mathrm{L})$. In other areas, the $\mathrm{Cd}$ content was relatively low, less than $0.15 \mu \mathrm{g} / \mathrm{L}$, conforming to the seawater standard of Class I $(1.00 \mu \mathrm{g} / \mathrm{L})$. Therefore, in terms of the $\mathrm{Cd}$ content, the water had good quality and reached the national seawater standard of Class I.

In September, the variation range of $\mathrm{Cd}$ content in the waters of Jiaozhou Bay was $0.07-0.23 \mu \mathrm{g} / \mathrm{L}$ (Figure 1). The high value area appeared in the eastern coastal waters of Jiaozhou Bay. In this area, station H3107, the $\mathrm{Cd}$ content was relatively high, which was $0.23 \mu \mathrm{g} / \mathrm{L}$, conforming to the seawater standard of Class I $(1.00 \mu \mathrm{g} / \mathrm{L})$. Except this area, the $\mathrm{Cd}$ content was relatively low in other water area of Jiaozhou Bay, less than $0.16 \mu \mathrm{g} / \mathrm{L}$, conforming to the seawater standard of Class I $(1.00 \mu \mathrm{g} / \mathrm{L})$. Therefore, in terms of the Cd content, the water had good quality and reached the national seawater standard of Class I.

In October, the variation range of $\mathrm{Cd}$ content in the waters of Jiaozhou Bay was $0.08-0.18 \mu \mathrm{g} / \mathrm{L}$ (Figure 1). The high value area appeared in the eastern coastal waters of Jiaozhou Bay. In this area, station H3107, the $\mathrm{Cd}$ content was relatively high, which was $0.18 \mu \mathrm{g} / \mathrm{L}$, conforming to the seawater standard of Class I $(1.00 \mu \mathrm{g} / \mathrm{L})$. Except this area, the $\mathrm{Cd}$ content was relatively low in other water area of Jiaozhou Bay, less than $0.16 \mu \mathrm{g} / \mathrm{L}$, conforming to the seawater standard of Class I $(1.00 \mu \mathrm{g} / \mathrm{L})$. Therefore, in terms of the Cd content, the water had good quality and reached the national seawater standard of Class I.

Therefore, the variation range of $\mathrm{Cd}$ content in the waters of Jiaozhou Bay was $0.07-0.23 \mu \mathrm{g} / \mathrm{L}$ in May, September and October, which conformed to the seawater standard of Class I. It indicated that in terms of $\mathrm{Cd}$ content, the water quality of entire waters of Jiaozhou Bay was not polluted by Cd at all (Figure 1).

Tab.1 The surface water quality in Jiaozhou bay in May, September and October

\begin{tabular}{|l|c|c|c|}
\hline & May & September & October \\
\hline $\begin{array}{l}\mathrm{Cd} \quad \mathrm{content} \text { in the } \\
\text { seawater } \mu \mathrm{g} \cdot \mathrm{L}^{-1} \\
\text { National seawater standard }\end{array}$ & $\begin{array}{c}0.09-0.18 \\
\text { Class I }\end{array}$ & $\begin{array}{c}0.07-0.23 \\
\text { Class I }\end{array}$ & $\begin{array}{c}0.08-0.18 \\
\text { Class I }\end{array}$ \\
\hline
\end{tabular}

\subsection{Horizontal distribution in the surface layer}

In May, in the northern coastal waters of Jiaozhou Bay, station $\mathrm{H} 3103$, the $\mathrm{Cd}$ content reached a relatively high level of $0.18 \mu \mathrm{g} / \mathrm{L}$, forming a high $\mathrm{Cd}$ content area with H3103 station as the center and a series of half oval circles with different gradients. The $\mathrm{Cd}$ content decreased from the high content of $0.18 \mu \mathrm{g} / \mathrm{L}$ in the center to the surroundings along the gradient, to $0.11 \mu \mathrm{g} / \mathrm{L}$ in the southeastern waters of the bay, $0.13 \mu \mathrm{g} / \mathrm{L}$ in the waters of bay mouth, and $0.09 \mu \mathrm{g} / \mathrm{L}$ in the southeastern waters of the bay (Figure 2).

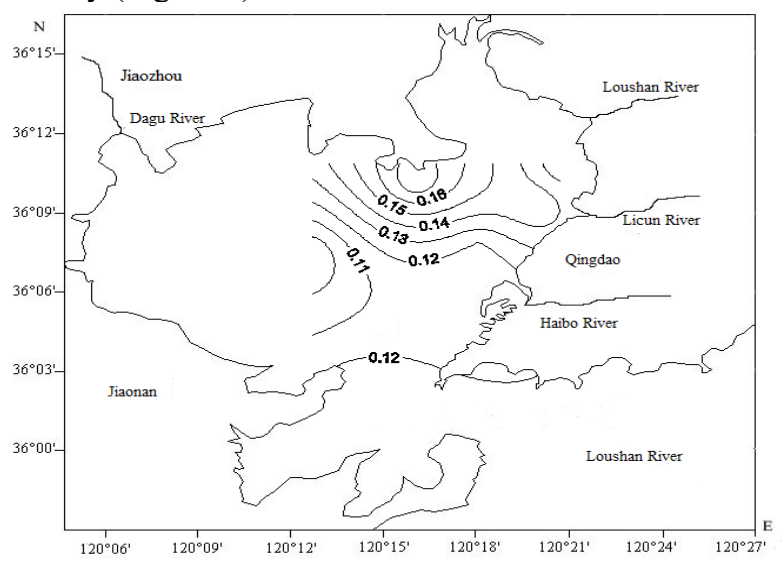

Fig. $2 \mathrm{Cd}$ content distribution in the surface layer in $\operatorname{May}(\mu \mathrm{g} / \mathrm{L})$

In September, in the eastern part of Jiaozhou Bay, station $\mathrm{H} 3107$, the $\mathrm{Cd}$ content reached a relatively high level of $0.23 \mu \mathrm{g} / \mathrm{L}$, forming a high content area of Cd with H3107 station as the center and a series of concentric circles with different gradients. The Cd content decreased from the high content of $0.23 \mu \mathrm{g} / \mathrm{L}$ in the center along the gradient to the surroundings, to $0.16 \mu \mathrm{g} / \mathrm{L}$ in the central waters of the bay, $0.09 \mu \mathrm{g} / \mathrm{L}$ in the waters of bay mouth, 
and $0.15 \mu \mathrm{g} / \mathrm{L}$ in the northern waters of the bay (Figure $3)$.

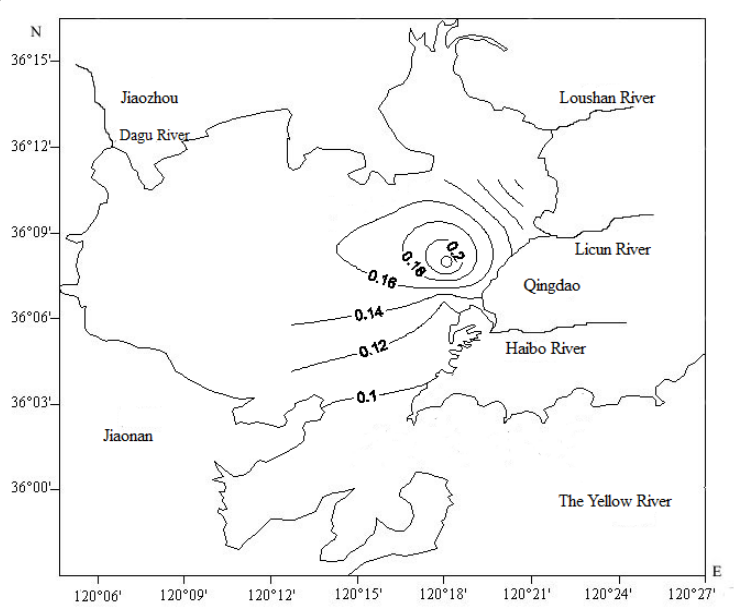

Fig.3 Cd content distribution in the surface layer in September $(\mu \mathrm{g} / \mathrm{L})$

In October, in the eastern part of Jiaozhou Bay, station $\mathrm{H} 3107$, the $\mathrm{Cd}$ content reached a relatively high level of $0.18 \mu \mathrm{g} / \mathrm{L}$, forming a high content area of Cd with $\mathrm{H} 3107$ station as the center and a series of concentric circles with different gradients. The Cd content decreased from the high content of $0.18 \mu \mathrm{g} / \mathrm{L}$ in the center along the gradient to the surroundings, to $0.14 \mu \mathrm{g} / \mathrm{L}$ in the central waters of the bay, $0.10 \mu \mathrm{g} / \mathrm{L}$ in the waters of bay mouth, and $0.08 \mu \mathrm{g} / \mathrm{L}$ in the northern waters of the bay (Figure 4).

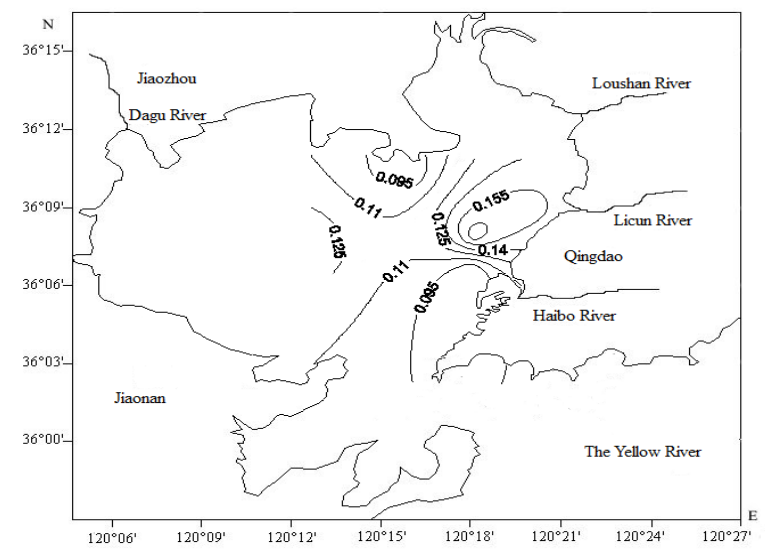

Fig.4 Cd content distribution in the surface layer in $\operatorname{October}(\mu \mathrm{g} / \mathrm{L})$

\section{Discussion}

\subsection{Water quality}

The variation range of $\mathrm{Cd}$ content in the waters of Jiaozhou Bay was $0.07-0.23 \mu \mathrm{g} / \mathrm{L}$ in May, September and October, which conformed to the seawater standard of Class I. It indicated that in terms of Cd content, in May, September and October, the water quality of entire waters of Jiaozhou Bay was not polluted by $\mathrm{Cd}$ at all.

In May, the content of $\mathrm{Cd}$ in the waters of Jiaozhou Bay ranged within $0.09-0.18 \mu \mathrm{g} / \mathrm{L}$, and the waterbody of Jiaozhou Bay was not polluted by $\mathrm{Cd}$ at all. In the northern coastal water area, the $\mathrm{Cd}$ content was relatively high, $0.018 \mu \mathrm{g} / \mathrm{L}$, which indicated that the water in this area did not get polluted by Cd. However, in other water areas, the $\mathrm{Cd}$ content was relatively low, far less than $1.00 \mu \mathrm{g} / \mathrm{L}$, which indicated that in terms of $\mathrm{Cd}$ content, the water in other areas was clean, in good quality and not polluted by $\mathrm{Cd}$.

In September, the content of $\mathrm{Cd}$ in the waters of Jiaozhou Bay ranged within $0.07-0.23 \mu \mathrm{g} / \mathrm{L}$, which indicated that the waterbody of Jiaozhou Bay was not polluted by $\mathrm{Cd}$ at all. In the eastern coastal water area, the $\mathrm{Cd}$ content reached the highest value, $0.23 \mu \mathrm{g} / \mathrm{L}$, which indicated that the water in this area did not get polluted by $\mathrm{Cd}$. However, in other water areas, the $\mathrm{Cd}$ content was relatively low, far less than $1.00 \mu \mathrm{g} / \mathrm{L}$, showing that in terms of $\mathrm{Cd}$ content, the water in other areas was clean, in good quality and not polluted by $\mathrm{Cd}$ at all.

In October, the content of $\mathrm{Cd}$ in the waters of Jiaozhou Bay ranged within $0.08-0.18 \mu \mathrm{g} / \mathrm{L}$, which indicated that the waterbody of Jiaozhou Bay was not polluted by $\mathrm{Cd}$ at all. In the eastern coastal water area, the $\mathrm{Cd}$ content reached a relatively high value, $0.18 \mu \mathrm{g} / \mathrm{L}$, which indicated that the water in this area did not get polluted by $\mathrm{Cd}$. However, in other water areas, the $\mathrm{Cd}$ content was relatively low, far less than $1.00 \mu \mathrm{g} / \mathrm{L}$, showing that in terms of $\mathrm{Cd}$ content, the water in other areas was clean, in good quality and not polluted by $\mathrm{Cd}$ at all.

\subsection{Sources}

In May, it existed an area with high $\mathrm{Cd}$ content in the northern coastal waters of Jiaozhou Bay, indicating that the source of $\mathrm{Cd}$ content was the surface runoff. Its $\mathrm{Cd}$ content reached a high value of $0.18 \mu \mathrm{g} / \mathrm{L}$, and the transported content was also relatively high.

In September, it existed an area with high $\mathrm{Cd}$ content in the eastern waters of Jiaozhou Bay, indicating that the $\mathrm{Cd}$ content sourced from atmospheric deposition. Its $\mathrm{Cd}$ content reached a high value of $0.23 \mu \mathrm{g} / \mathrm{L}$, and the transported content was also high.

In October, it existed an area with high $\mathrm{Cd}$ content in the eastern waters of Jiaozhou Bay, indicating that the $\mathrm{Cd}$ content sourced from atmospheric deposition. Its $\mathrm{Cd}$ content reached a high value of $0.18 \mu \mathrm{g} / \mathrm{L}$, and the transported content was relatively high.

In May, the $\mathrm{Cd}$ content of surface runoff transported to Jiaozhou Bay was $0.18 \mu \mathrm{g} / \mathrm{L}$, which met the national seawater quality standard of Class I, $1.00 \mu \mathrm{g} / \mathrm{L}$. This showed that the surface runoff was not contaminated by any $\mathrm{Cd}$ content (Table 2). In September, the Cd content transported by atmospheric deposition to Jiaozhou Bay was $0.23 \mu \mathrm{g} / \mathrm{L}$, which met the national seawater quality standard of Class I, $1.00 \mu \mathrm{g} / \mathrm{L}$. This showed that atmospheric deposition was not polluted by $\mathrm{Cd}$ content (Table 2). In October, the $\mathrm{Cd}$ content transported by atmospheric deposition to Jiaozhou Bay was $0.18 \mu \mathrm{g} / \mathrm{L}$, which met the national seawater quality standard of Class I, $1.00 \mu \mathrm{g} / \mathrm{L}$. This indicated that atmospheric deposition was polluted by $\mathrm{Cd}$ content at all (Table 2). Therefore, the $\mathrm{Cd}$ content transported by surface runoff and atmospheric deposition to Jiaozhou Bay met the national 
seawater quality standard of Class I, $1.00 \mu \mathrm{g} / \mathrm{L}$, which showed that neither surface runoff nor atmospheric sedimentation was polluted by $\mathrm{Cd}$ content.

Tab.2 The Cd contents from the different sources in Jiaozhou bay

\begin{tabular}{|c|c|c|}
\hline Various sources & $\begin{array}{c}\text { Transportation of } \\
\text { surface runoff }\end{array}$ & $\begin{array}{c}\text { Transportation of atmospheric } \\
\text { deposition }\end{array}$ \\
\hline $\mathrm{Cd}$ content/ $/ \mathrm{g} \cdot \mathrm{L}-1$ & 0.18 & $0.18-0.23$ \\
\hline
\end{tabular}

\subsection{Input volume from different sources}

There were two sources of Cd content in the waters of Jiaozhou Bay, the transportation of surface runoff and the transportation of atmospheric deposition. The $\mathrm{Cd}$ content from surface runoff transportation was $0.18 \mu \mathrm{g} / \mathrm{L}$, and the $\mathrm{Cd}$ content from atmospheric deposition was $0.18-0.23 \mu \mathrm{g} / \mathrm{L}$. Therefore, there were two ways to transport Cd content to the waters of Jiaozhou Bay: 1) transportation of surface runoff, and 2) transportation of atmospheric deposition. This determined that although the paths of transporting $\mathrm{Cd}$ content were different, the range of the final $\mathrm{Cd}$ content that reached the ocean water body was $0.18-0.23 \mu \mathrm{g} / \mathrm{L}$ (Figure 5 ). The order of $\mathrm{Cd}$ content transported to Jiaozhou Bay waters is as follows: $\mathrm{Cd}$ content transported from atmospheric deposition, $0.18-0.23 \mu \mathrm{g} / \mathrm{L} \geq \mathrm{Cd}$ content transported by surface runoff, $0.18 \mu \mathrm{g} / \mathrm{L}$. Cd content transported by atmospheric deposition and surface runoff was very close.

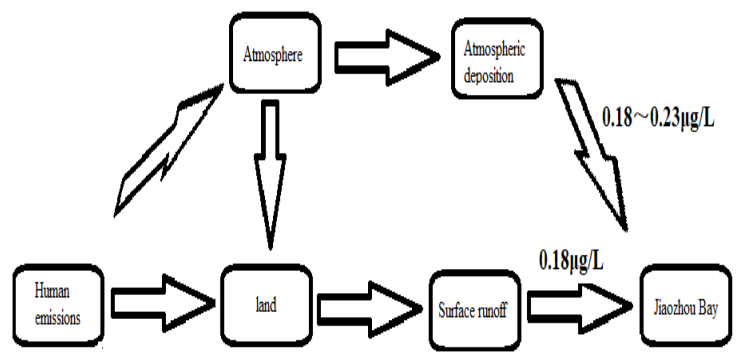

Fig.5 The migration paths and input volume of $\mathrm{Cd}$ content $(\mu \mathrm{g} / \mathrm{L})$

The Cd content emitted by humans into the atmosphere was the same as the Cd content emitted by humans into the land, and it was very low, $0.18-0.23 \mu \mathrm{g} / \mathrm{L}$, far less than $1.00 \mu \mathrm{g} / \mathrm{L}$. This reveals that the humans had realized the importance of environmental protection, so the emission to the environment was very low. The atmosphere, land and sea were not polluted by $\mathrm{Cd}$ content. Moreover, humans mainly emitted $\mathrm{Cd}$ content into the atmosphere and then settled on land. In this way, the $\mathrm{Cd}$ content transported by atmospheric deposition was $0.18-0.23 \mu \mathrm{g} / \mathrm{L} \geq 0.18 \mu \mathrm{g} / \mathrm{L}$ that transported by surface runoff.

\section{Conclusion}

The variation range of $\mathrm{Cd}$ content in the waters of Jiaozhou Bay was $0.07-0.23 \mu \mathrm{g} / \mathrm{L}$ in May, September and October, which conformed to the seawater standard of
Class I. It indicated that in terms of Cd content, in May, September and October, the water quality of entire waters of Jiaozhou Bay was not polluted by $\mathrm{Cd}$ at all.

In May, the content of $\mathrm{Cd}$ in the waters of Jiaozhou Bay ranged within $0.09-0.18 \mu \mathrm{g} / \mathrm{L}$, and the waterbody of Jiaozhou Bay was not polluted by $\mathrm{Cd}$ at all. In the northern coastal water area, the $\mathrm{Cd}$ content was relatively high, $0.018 \mu \mathrm{g} / \mathrm{L}$, which indicated that the water in this area did not get polluted by $\mathrm{Cd}$. In other water areas, the $\mathrm{Cd}$ content was relatively low, far less than $1.00 \mu \mathrm{g} / \mathrm{L}$, which indicated that in terms of Cd content, the water in other areas was clean, in good quality and not polluted by Cd.

In September, the content of $\mathrm{Cd}$ in the waters of Jiaozhou Bay ranged within $0.07-0.23 \mu \mathrm{g} / \mathrm{L}$, which indicated that the waterbody of Jiaozhou Bay was not polluted by $\mathrm{Cd}$ at all. In the eastern coastal water area, the $\mathrm{Cd}$ content reached the highest value, $0.23 \mu \mathrm{g} / \mathrm{L}$, which indicated that the water in this area did not get polluted by $\mathrm{Cd}$. In other water areas, the $\mathrm{Cd}$ content was relatively low, far less than $1.00 \mu \mathrm{g} / \mathrm{L}$, showing that in terms of $\mathrm{Cd}$ content, the water in other areas was clean, in good quality and not polluted by $\mathrm{Cd}$ at all.

In October, the content of $\mathrm{Cd}$ in the waters of Jiaozhou Bay ranged within $0.08-0.18 \mu \mathrm{g} / \mathrm{L}$, which indicated that the waterbody of Jiaozhou Bay was not polluted by $\mathrm{Cd}$ at all. In the eastern coastal water area, the $\mathrm{Cd}$ content reached a relatively high value, $0.18 \mu \mathrm{g} / \mathrm{L}$, which indicated that the water in this area did not get polluted by $\mathrm{Cd}$. In other water areas, the $\mathrm{Cd}$ content was relatively low, far less than $1.00 \mu \mathrm{g} / \mathrm{L}$, showing that in terms of $\mathrm{Cd}$ content, the water in other areas was clean, in good quality and not polluted by $\mathrm{Cd}$ at all.

The Cd content in the waters of Jiaozhou Bay mainly came from two sources, the transport of surface runoff and the transport of atmospheric deposition. The $\mathrm{Cd}$ content from surface runoff transportation was $0.18 \mu \mathrm{g} / \mathrm{L}$, and the $\mathrm{Cd}$ content from atmospheric deposition transportation was $0.18-0.23 \mu \mathrm{g} / \mathrm{L}$.

There were two ways to transport Cd content to the waters of Jiaozhou Bay: 1) transportation of surface runoff, and 2) transportation of atmospheric deposition. The order of $\mathrm{Cd}$ content transported to Jiaozhou Bay waters is as follows: $\mathrm{Cd}$ content transported from atmospheric deposition, $0.18-0.23 \mu \mathrm{g} / \mathrm{L} \geq \mathrm{Cd}$ content transported by surface runoff, $0.18 \mu \mathrm{g} / \mathrm{L} . \mathrm{Cd}$ content transported by atmospheric deposition and surface runoff was very close and very low, within $0.18-0.23 \mu \mathrm{g} / \mathrm{L}$, far less than $1.00 \mu \mathrm{g} / \mathrm{L}$. This revealed that the humans had realized the importance of environmental protection, and the emissions to the environment were very low. The atmosphere, land and sea were not polluted by $\mathrm{Cd}$ content. The $\mathrm{Cd}$ content transported by atmospheric deposition $0.18-0.23 \mu \mathrm{g} / \mathrm{L} \geq$ the Cd content transported by surface runoff $0.18 \mu \mathrm{g} / \mathrm{L}$, which indicated that the $\mathrm{Cd}$ content was mainly discharged into the atmosphere by humans and then deposited on the land. 


\section{Acknowledgement}

This research was sponsored by Doctoral Degree Construction Library of Guizhou Nationalities University and Research Projects of Guizhou Nationalities University ([2014]02), Research Projects of Guizhou Province Ministry of Education (KY [2014] 266), Research Projects of Guizhou Province Ministry of Science and Technology (LH [2014] 7376).

\section{References}

1. Dongfang Yang, Zhenqing Miao. Marine Bay Ecology (Volume 1) [M]. Beijing: China Ocean Press, 2010, 1-320.

2. Dongfang Yang, Zhenhui Gao. Marine Bay Ecology (Volume 2) [M]. Beijing: China Ocean Press, 2010, 1-330.

3. Dongfang Yang, Yu Chen, Hong Wang, Chunru Yang, Junhui Guo. Environmental Background Composition and Transfer Process of Cadmium in Jiaozhou Bay [J]. Coastal Engineering, 2010, 29 (4): 73-82.

4. Dongfang Yang, Yu Chen, Yanxiang Chang, Chunxiu Liu, Yichan Weng. The Source and Distribution of Cadmium in Jiaozhou Bay [J]. Coastal Engineering, 2013, 32 (3): 68-78.

5. Dongfang Yang, Sixi Zhu, Fengyou Wang, Huazhong He and Yunjie Wu. The distribution and content of Cadmium in Jiaozhou Bay [J]. Applied Mechanics and Materials Vols.644-650. 2014, 5325-5328.

6. Dongfang Yang, Fengyou Wang, Youfu Wu, Huazhong $\mathrm{He}$ and Sixi Zhu. The structure of environmental background value of Cadmium in Jiaozhou Bay waters [J]. Applied Mechanics and Materials Vols.644-650. 2014, 5329-5312.

7. Dongfang Yang, Shengtao Chen, Baolei Li, Xiao Geng and Zijun Xu. Research on the vertical distribution of Cadmium in Jiaozhou Bay waters [J]. Proceedings of the 2015 international symposium on computers and informatics. 2015, 2667-2674.

8. YANG D F, CHEN Y, GAO Z H, et al. Silicon Limitation on primary production and its destiny in Jiaozhou Bay, China IV transect offshore the coast with estuaries [J]. Chin. J. Oceanol. Limnol. 2005, 23(1): 72-90.

9. Dongfang Yang, Fan Wang, Zhenhui Gao, et al. Ecological Phenomena of Phytoplankton in Jiaozhou Bay [J]. Marine Science, 2004, 28 (6): 71-74.

10. State Oceanic Administration. The Specification for Marine Monitoring (HY003.4-91) [M]. Beijing: China Ocean Press, 1991, 205-282. 